\title{
Hidrolisis Protein Isolat Biji Melinjo (Gnetum gnemon L.) menggunakan Alkalase Terimobilisasi dan Aktivitasnya sebagai Antihipertensi (Hydrolysis of Melinjo Seed (Gnetum gnemon L.) Isolated-Protein using Immobilized Alcalase and Its Activity as Antihypertensive)
}

\author{
Nur Fauziah Matra ${ }^{1}$, Endah Puspitasari ${ }^{1}$, Tri Agus Siswoyo ${ }^{2}$ \\ ${ }^{1}$ Fakultas Farmasi, Universitas Jember \\ ${ }^{2}$ Center for Development of Advanced Sciences and Technology (CDAST), Universitas Jember, Fakultas \\ Pertanian, Universitas Jember \\ Jalan Kalimantan 37, Jember 68121 \\ email korespondensi: triagus.faperta@unej.ac.id
}

\begin{abstract}
Hypertension is ranked third on the cause of death in Indonesia for all ages (6.8\%). Protein isolate of melinjo seeds (Gnetum gnemon L.) hydrolyzed with free alcalase has been known to have antihypertensive activity. However, the use of free alcalase is uneconomical since it can only be used once, thus we studied the immobilized alcalase effectivity to hydrolise the melinjo seeds protein isolate to be used as angiotensin converting enzyme (ACE) inhibitor. The immobilization method used entrapment method with DMDMOS/TMOS as matrix. Characterization of the immobilized enzyme was observed by FTIR and effectiveness of repeated hydrolysis was observed by the value of the degree of hydrolysis. The success of the hydrolysis process was determined by SDS-PAGE electrophoresis. Antihypertensive activity test was determined by the ability to inhibit ACE. The results showed that the alcalase has been immobilized in the matrix of silane and SDS-PAGE protein profile showed melinjo seed proteins had been successfully hydrolyzed. Hydrolysis process repeatedly demonstrated that immobilized alcalase was effective to hydrolyze protein isolates of melinjo seeds twice. Based on ACE inhibitory test, there were no significant differences between the protein isolate hydrolyzed by immobilized alcalase $(\mathrm{Gg}-\mathrm{PH})$, protein isolates hydrolyzed with free alcalase (Gg-PHB), and captopril. These findings suggest that the antihypertensive activity in $\mathrm{Gg}-\mathrm{PH}$ is the same with that of captopril.
\end{abstract}

Keywords: hypertension, antihypertensive, melinjo, enzymes immobilization, ACE inhibitor

\begin{abstract}
Abstrak
Hipertensi menduduki peringkat ketiga dari penyebab kematian utama di Indonesia untuk semua umur $(6,8 \%)$. Protein isolat biji melinjo yang dihidrolisis dengan alkalase bebas telah diketahui memiliki aktivitas sebagai antihipertensi. Namun penggunaan alkalase bebas tidak ekonomis dan hanya dapat digunakan sekali saja, sehingga kami melakukan penelitian tentang efektivitas alkalase terimobilisasi untuk menghidrolisis protein isolat biji melinjo sebagai antihipertensi. Metode imobilisasi enzim yang digunakan adalah metode penjerapan dengan DMDMOS/TMOS sebagai matriks. Karakterisasi enzim terimobilisasi diamati dengan FTIR dan efektivitas hidrolisis berulang diamati berdasarkan nilai derajat hidrolisis. Keberhasilan proses hidrolisis ditentukan dengan elektroforesis SDS-PAGE. Uji aktivitas antihipertensi ditentukan dengan melihat kemampuan dalam menghambat angiotensin converting enzyme (ACE). Hasil menunjukkan bahwa enzim alkalase telah terimobilisasi di dalam matriks silan dan profil protein SDS-PAGE menunjukkan protein biji melinjo telah berhasil dihidrolisis. Hidrolisis berulang menunjukkan enzim alkalase terimobilisasi efektif menghidrolisis protein isolat biji melinjo hingga dua kali. Berdasarkan uji aktivitas ACE inhibitor, tidak ada perbedaan yang signifikan antara protein isolat yang dihidrolisis dengan alkalase terimobilisasi $(\mathrm{Gg}-\mathrm{PH})$, protein isolat yang dihidrolisis dengan alkalase bebas (Gg-PHB), dan kaptopril. Hal ini menunjukkan bahwa aktivitas antihipertensi pada Gg-PH sama dengan aktivitas antihipertensi pada kaptopril.
\end{abstract}

Kata kunci: hinertensi. antihinertensi. melinio. imobilisasi enzim. ACE inhibitor 


\section{Pendahuluan}

Hipertensi menduduki peringkat ketiga dari penyebab kematian utama di Indonesia untuk semua umur $(6,8 \%)$, setelah stroke $(15,4 \%)$ dan tuberkulosis $(7,8 \%)$. Hipertensi ditandai dengan peningkatan tekanan darah sistolik lebih dari $140 \mathrm{mmHg}$ dan tekanan darah diastolik lebih dari $90 \mathrm{mmHg}$ [1]. Sistem renin angiotensin mempunyai peranan penting dalam pengaturan tekanan darah [2]. Renin yang disekresi oleh ginjal berfungsi mengubah angiotensinogen menjadi angiotensin I. Selanjutnya oleh ACE, angiotensin I diubah menjadi angiotensin II yang dapat menyebabkan penyempitan pembuluh darah (vasokonstriksi), sehingga terjadi peningkatan tekanan darah.

Siswoyo dan Sugiharto [3] menyebutkan bahwa protein isolat biji melinjo yang dihidrolisis menggunakan alkalase bebas memiliki aktivitas sebagai antihipertensi. Namun penggunaan enzim bebas tidak ekonomis dan hanya dapat digunakan sekali saja. Hal tersebut dapat diatasi dengan teknik imobilisasi enzim. Imobilisasi enzim didefinisikan sebagai enzim yang secara fisik ditempatkan dalam suatu matriks padat (support) dengan tetap memiliki aktivitas katalitiknya [4]. Salah satu metode imobilisasi enzim, yakni metode penjerapan (entrapment) merupakan metode yang paling mudah dan efektif untuk teknik imobilisasi enzim [5]. Melalui teknik modifikasi ini diharapkan dapat meminimalisir penggunaan enzim yang tidak ekonomis, sehingga produksi protein hidrolisat yang memiliki aktivitas sebagai antihipertensi dapat terpenuhi secara cepat. Tujuan dari penelitian ini adalah untuk mengetahui efektivitas enzim alkalase terimobilisasi dalam menghidrolisis protein secara berulang dan mengetahui aktivitas antihipertensi protein biji melinjo.

\section{Metode Penelitian}

Jenis penelitian yang digunakan adalah true experimental laboratories. Pemilihan sampel dilakukan secara acak. Sampel yang digunakan adalah biji melinjo yang telah masak secara fisiologis, ditandai dengan kulit luar berwarna merah. Biji melinjo diperoleh dari petani di daerah Kalibaru, Kabupaten Banyuwangi, yang dipanen pada bulan Juli 2015 pada pagi hari. Terdapat 4 kelompok perlakuan, yaitu kelompok kontrol positif (kaptopril), kelompok protein isolat (Gg-PI), kelompok protein yang dihidrolisis dengan alkalase terimobilisasi $(\mathrm{Gg}-\mathrm{PH})$, dan kelompok protein yang dihidrolisis dengan alkalase bebas (GgPHB). Masing-masing kelompok diuji aktivitas antihipertensi-nya pada berbagai konsentrasi $(0,0002 ; \quad 0,002 ; \quad 0,02 ; \quad 0,2 ; \quad$ dan $2 \mu \mathrm{g} / \mu \mathrm{l})$. Penelitian ini dilakukan di laboratorium CDAST Universitas Jember pada bulan September 2015-selesai.

\section{Alat dan bahan}

Alat yang digunakan pada penelitian ini adalah shaker incubator (Stuart S1600), oven (Carbolite), sentrifuse (Tomy MRX-150 dan Hitachi CR21GIII), spektrofotometer (Hitachi tipe U-2900 UV-Vis), elektroforesis SDS-PAGE (Bio-Rad), dry block heater (Techne), FTIR (Bruker Alfa), stirer, vortex, timbangan analitik, blender, mikropipet, dan syiringe Hamilton.

Bahan yang digunakan adalah biji melinjo; akuades; 0,2 M buffer fosfat $\mathrm{pH}$ 8; $1 \mathrm{M}$ $\mathrm{HCl}$; $1 \mathrm{M} \mathrm{NaOH}$; 0,1 M Na2SO3; enzim alkalase $24 \mathrm{~L} \mathrm{FG} \mathrm{(2,4} \mathrm{AU/g}$ dan densitasnya $1,18 \mathrm{~g} / \mathrm{mL})$; $0,1 \%$ reagen asam trinitro benzen sulfonat (TNBS); reagen Bradford; PEG 20000; $1 \mathrm{M} \mathrm{NaF}$ (Wako); isopropil alkohol; bovine serum albumin (BSA) (Sigma); dimetil dimetoksi silan (DMDMOS) (Ald rich); tetrametil ortosilikat (TMOS) (Shin etsu); standar L-leusin (Wako), dan seperangkat bahan SDS-PAGE.

\section{Imobilisasi enzim alkalase}

Dalam gelas vial $10 \mathrm{ml}$, larutan alkalase 3,12 mL, PEG 2000 0,8 mL, NaF 0,4 mL, dan isopropil alkohol $0,8 \mathrm{~mL}$ dicampur dan dihomogenkan menggunakan stirer magnetik pada kecepatan $600 \mathrm{rpm}$. Kemudian ditambahkan 24 mmol DMDMOS/TMOS (1:1). Larutan diaduk pada suhu ruang hingga terbentuk gel. Gel yang diperoleh dikeringkan dalam ruang dingin $\left(4^{\circ} \mathrm{C}\right)$. Karakterisasi enzim terimobilisasi diamati menggunakan FTIR.

\section{Ekstraksi dan isolasi protein biji melinjo}

Sampel (25 gram) dihaluskan dengan menambahkan $75 \mathrm{~mL}$ akuades (1:3). Kemudian disaring dan suspensi yang diperoleh disentrifugasi selama 10 menit dengan kecepatan $10.000 \mathrm{rpm}$ pada suhu $15^{\circ} \mathrm{C}$. Selanjutnya supernatan (Gg-PK) diatur pH-nya menjadi 4 dengan menggunakan $1 \mathrm{M} \mathrm{HCl}$ untuk dapat mempresipitasi protein. Kemudian suspensi dibiarkan selama 30 menit untuk memungkinkan protein dapat terendapkan secara sempurna. Setelah itu larutan disentrifugasi pada kecepatan $10.000 \mathrm{rpm}$ selama 10 menit pada suhu $15^{\circ} \mathrm{C}$. Endapan protein $(\mathrm{Gg}-\mathrm{PI})$ yang diperoleh diresuspensi 
dengan akuades dan diatur $\mathrm{pH}$-nya menjadi 8 menggunakan $\mathrm{NaOH} 1 \mathrm{~N}$.

\section{Hidrolisis protein isolat biji melinjo} Optimasi kondisi dilakukan terlebih dahulu sebelum melaksanakan hidrolisis protein. Optimasi yang dilakukan adalah optimasi suhu inkubasi $\left(30,40,50\right.$, dan $\left.60^{\circ} \mathrm{C}\right)$, waktu inkubasi $(0,5,1,2,4,6,12,18$, dan 24 jam $)$, jumlah enzim $(1,5,10$, dan $20 \mathrm{mg})$, dan konsentrasi substrat $(2,4,5,6$, dan $8 \mathrm{mg} / \mathrm{mL})$. Proses hidrolisis didasarkan pada metode yang telah dilakukan oleh Siswoyo dan Sugiharto [6]. Protein isolat $200 \mu \mathrm{l}$ ditambahkan dengan enzim terimobilisasi dan buffer fosfat $(\mathrm{pH} 8) 300 \mu \mathrm{l}$. Campuran kemudian diinkubasi dan hasilnya disentrifus dengan kecepatan $10.000 \mathrm{rpm}$ selama 10 menit pada suhu $25^{\circ} \mathrm{C}$. Bagian supernatan diambil sebagai protein hidrolisat biji melinjo (Gg-PH) yang selanjutnya ditentukan derajat hidrolisisnya. Semua pengujian dilakukan tiga kali replikasi. Derajat hidrolisis ditentukan menggunakan metode TNBS [7]. Sampel $5 \mu \mathrm{l}$ dicampur dengan $400 \mu \mathrm{l} 0,2 \mathrm{M}$ buffer fosfat $(\mathrm{pH}$ 8) dan $200 \mu \mathrm{l} 0,1 \%$ TNBS, kemudian diinkubasi selama 30 menit pada suhu $50^{\circ} \mathrm{C}$. Reaksi dihentikan dengan menambahkan $400 \quad \mu l \quad 0,1 \quad \mathrm{~N}^{\mathrm{Na}_{2} \mathrm{SO}_{3}}$ lalu didinginkan pada suhu ruang, kemudian dibaca absorbansinya pada panjang gelombang 420 $\mathrm{nm}$. Kurva standart L-leucine digunakan untuk mengetahui konsentrasi asam amino. Persentasi derajat hidrolisis (DH) ditentukan dengan persamaan sebagai berikut:

$$
\mathrm{DH}=\frac{\mathrm{h}}{\mathrm{htot}} \times 100
$$

$\mathrm{h}$ adalah jumlah ikatan peptida yang dihidrolisis dan $\mathrm{h}_{\text {tot }}$ adalah jumlah total ikatan peptida per ekuivalen protein.

\section{Penentuan total protein terlarut}

Kandungan protein diukur dengan metode Bradford [8]. Sampel sebanyak $5 \quad \mu l$ ditambahkan dengan $45 \mu$ l akuades dan ditambah dengan $950 \mu \mathrm{l}$ reagen Bradford, kemudian absorban diukur pada panjang gelombang $\lambda 595 \mathrm{~nm}$. Hasil yang diperoleh dibandingkan dengan standar BSA (konsentrasi $1,5,10,15$, dan $20 \mu \mathrm{g} / \mu \mathrm{l})$ untuk mengetahui kandungan protein terlarut. Protein kemudian ditentukan berat molekulnya menggunakan SDS-PAGE sesuai dengan metode Laemmli [9].

\section{Uji aktivitas antihipertensi protein biji melinjo}

Aktivitas antihipertensi ditentukan dengan menggunakan ACE kit-WST-1 [10]. Larutan sampel dipreparasi dengan proses pengenceran (konsentrasi sampel $2 \mu \mathrm{l}$ ). Pengujian dilakukan dengan menambahkan 20 $\mu$ l larutan sampel, $20 \mu$ l buffer substrat, dan 20 $\mu$ l larutan kerja enzim ke dalam microplate. Blanko 1 dibuat dengan menambahkan $20 \mu \mathrm{l}$ akuades, $20 \mu \mathrm{l}$ buffer substrat, dan $20 \mu \mathrm{l}$ larutan kerja enzim ke dalam microplate. Sedangkan, blanko 2 dibuat dengan menambahkan $40 \mu \mathrm{l}$ akuades dan $20 \mu \mathrm{l}$ buffer substrat ke dalam microplate. Kemudian diinkubasi selama 1 jam pada suhu $37^{\circ} \mathrm{C}$. Selanjutnya, dimasukkan $200 \quad \mu l$ larutan indikator dan diinkubasi kembali selama 10 menit pada suhu ruang. Ukur absorbansi pada panjang gelombang $450 \mathrm{~nm}$. Kemudian ditentukan aktivitas ACE inhibitor dan analisis IC50. Aktivitas ACE inhibitor dapat dihitung dengan persamaan sebagai berikut::

$$
\text { ACE inhibitor }=\frac{(\text { Ablanko1 }- \text { Asampel })}{\text { Ablanko1 }- \text { Ablanko2 }} \times 100
$$

A adalah absorbansi

\section{Analisis data}

Data dianalisis menggunakan analistis statistik one way ANOVA.

\section{Hasil Penelitian}

Karakterisasi enzim alkalase terimobilisasi dengan FTIR ditunjukkan pada Gambar 1.

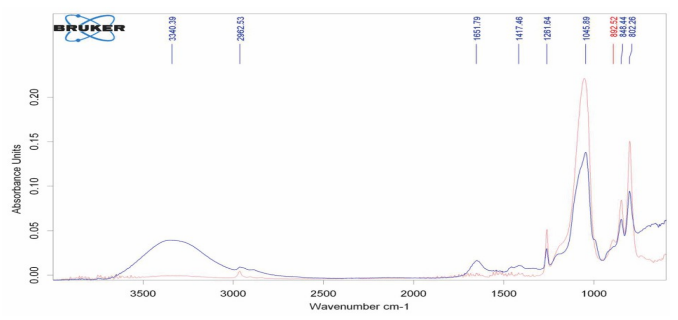

Gambar 1.Spektra FTIR matriks dan enzim alkalase terimobilisasi. Garis merah menunjukkan spektra enzim matrik, garis biru menunjukkan spektra enzim alkalase terimobilisasi

Gambar 1 menunjukkan adanya perbedaan antara spektra matriks (garis merah) dengan spektra enzim alkalase terimobilisasi (garis biru). Spektra dominan muncul pada 
pada daerah serapan antara $3.000-3.500 \mathrm{~cm}^{-1}$ dan $1000-1500 \mathrm{~cm}^{-1}$.

Hasil estraksi dan isolasi protein biji melinjo menunjukkan bahwa Gg-PI memiliki konsentrasi protein tertinggi (Tabel 1).

Tabel 1. Hasil produksi bertahap protein biji melinjo

\begin{tabular}{cccc}
\hline $\begin{array}{c}\text { Sampel } \\
\mathbf{u j i}\end{array}$ & $\begin{array}{c}\text { Volume } \\
(\mathbf{m L})\end{array}$ & $\begin{array}{c}\text { Konsentrasi } \\
(\boldsymbol{\mu} \mathbf{g} / \mathbf{\mu l})\end{array}$ & $\begin{array}{c}\text { Total } \\
\text { protein } \\
(\mathbf{m g})\end{array}$ \\
\hline $\mathrm{Gg}-\mathrm{PK}$ & 42 & 6,401 & 268,842 \\
$\mathrm{Gg}-\mathrm{Pl}$ & 19 & 7,225 & 137,275 \\
$\mathrm{Gg}-\mathrm{PH}$ & 11 & 2,710 & 29,81 \\
\hline
\end{tabular}

Berdasarkan hasil optimasi, diperoleh kondisi optimal untuk hidrolisis protein yaitu pada suhu inkubasi $50^{\circ} \mathrm{C}$ dengan derajat hidrolisis sebesar $44,11 \pm 3,36 \%$, waktu hidrolisis selama 4 jam dengan derajat hidrolisis sebesar 30,72 $\pm 0,14 \%$, jumlah enzim $5 \mathrm{mg}$ dengan derajat hidrolisis sebesar 57,12 $\pm 0,68$ $\%$, dan konsentrasi substrat $5 \mathrm{mg} / \mathrm{mL}$ dengan derajat hidrolisis sebesar 38,01 $\pm 0,64 \%$ (Gambar 2)

Selanjutnya hasil hidrolisis berulang ditunjukkan pada Gambar 3. Hasil menunjukkan bahwa enzim alkalase terimobilisasi efektif menghidrolisis protein hingga penggunaan yang kedua. Hasil elektroforesis SDS-PAGE menunjukkan terdapat empat pita protein dengan berat molekul yang berbeda yakni \pm 76 , $\pm 63, \pm 26$, dan \pm 14 Kda. Hasil SDS-PAGE ditunjukkan pada Gambar 4.

Aktivitas ACE inhibitor meningkat seiring dengan bertambahnya konsentrasi uji (Gambar 5). Gambar 5, menunjukkan bahwa Gg-PI memiliki aktivitas $A C E$ inhibitor paling rendah. Nilai $\mathrm{IC}_{50}$ dari $\mathrm{Gg}-\mathrm{PH}, \mathrm{Gg}-\mathrm{PHB}$, dan kaptopril dapat dilihat pada Tabel 2. Analisis statistik menunjukkan tidak ada perbedaan yang signifikan di antara ketiganya (LSD, $p>0,05$ ).

Tabel 2. Nilai $\mathrm{IC}_{50} \quad \mathrm{Gg}-\mathrm{PH}, \mathrm{Gg}-\mathrm{PHB}$, dan kaptopril.

\begin{tabular}{|c|c|}
\hline Sampel & Nilai IC $50(\mu \mathrm{g} / \mu \mathrm{l})$ \\
\hline $\mathrm{Gg}-\mathrm{PH}$ & $2,457 \pm 0,213^{a}$ \\
\hline Gg-PHB & $2,214 \pm 0,195^{a}$ \\
\hline Kaptopril & $2,085 \pm 0,202^{a}$ \\
\hline Keterangan: & $\begin{array}{l}\text { Notasi huruf sama yang } \\
\text { menunjukkan } \begin{array}{r}\text { tidak ada } \\
\text { perbedaan } \\
(L S D, p>0,05)\end{array}\end{array}$ \\
\hline
\end{tabular}
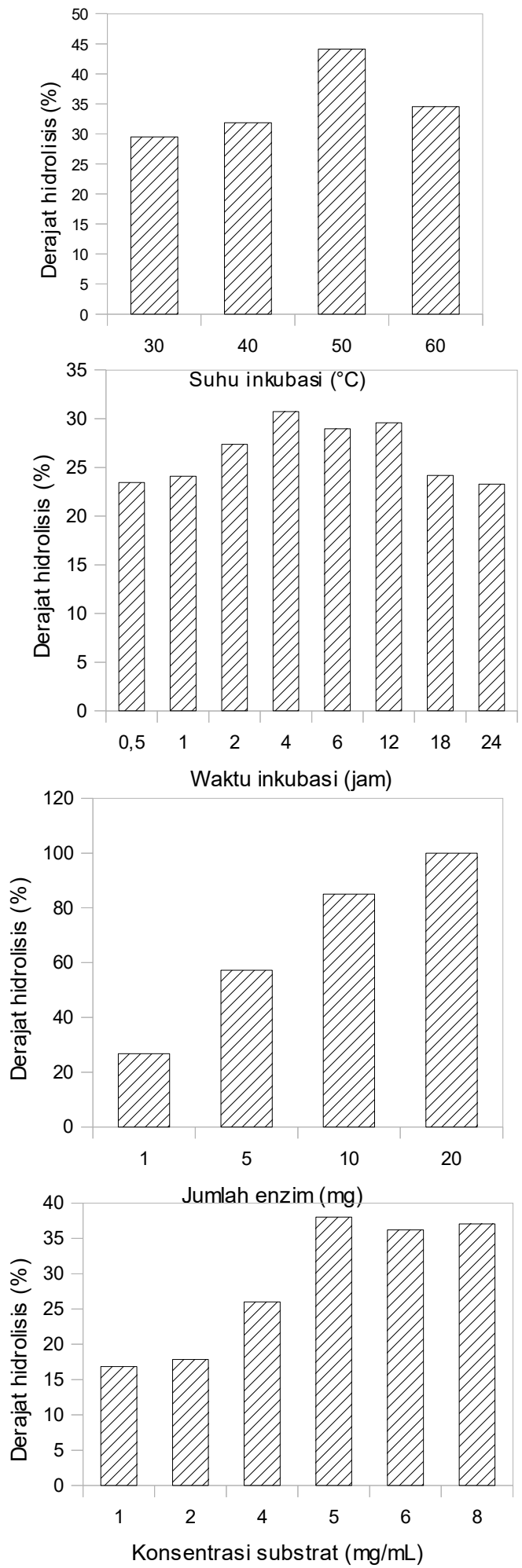

Gambar 2. Persentasi derajat hidrolisis $(\mathrm{DH})$ protein biji melinjo hasil optimasi. 


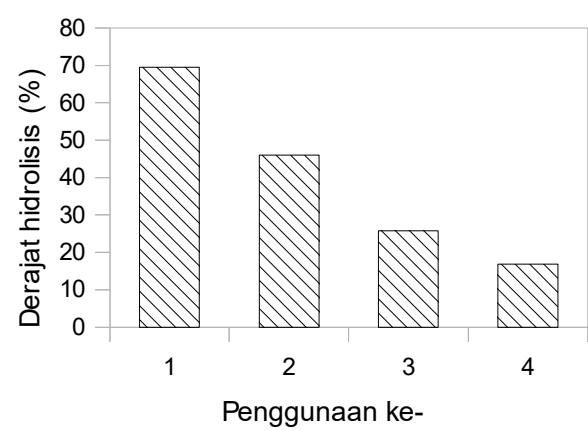

Gambar 3. Persentasi derajat hidrolisis (DH) pada beberapa kali penggunaan

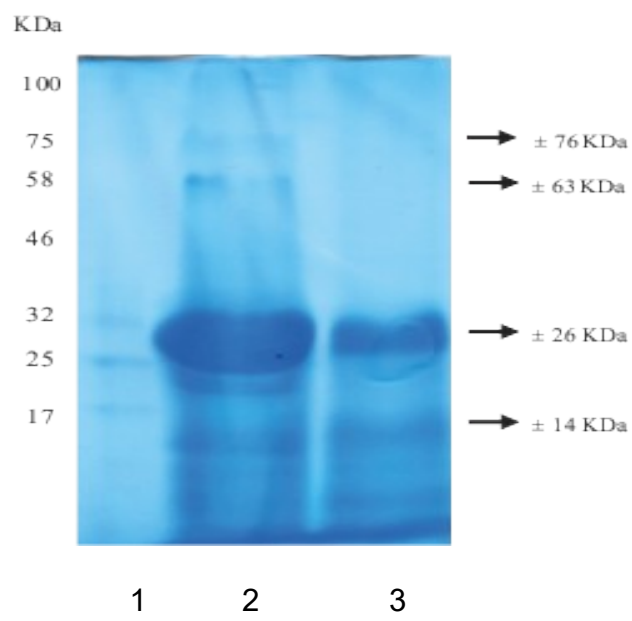

Gambar 4. Hasil SDS-PAGE protein biji melinjo.

(1) marker protein; (2) Gg-PK; (3) Gg-PH

\section{Pembahasan}

\section{Karakterisasi imobilisasi enzim}

Gambar 1 menunjukkan pada daerah serapan antara 3.000-3.500 $\mathrm{cm}^{-1}$, spektra matriks (garis merah) memiliki intensitas yang rendah, ditandai dengan nilai absorbansi yang mendekati nol. Sedangkan pada daerah serapan yang sama, spektra enzim alkalase terimobilisasi (garis biru) memiliki intensitas yang tinggi (nilai absorbansi 0,05). Hal ini menunjukkan bahwa telah terjadi interaksi antara enzim dengan matriks yang menghasilkan gugus $\mathrm{OH}$. Menurut Gokgoz dan Yigitoglu [11] daerah di antara 3.000 dan 3.700 $\mathrm{cm}^{-1}$ merupakan daerah serapan gugus $\mathrm{OH}$ paling kuat.

Spektra matriks di daerah serapan $1.045 \mathrm{~cm}^{-1}$ memiliki intensitas yang tinggi. Sedangkan spektra enzim alkalase terimobilisasi memiliki intensitas yang rendah pada daerah serapan yang sama. Hal ini menunjukkan bahwa adanya interkasi antara matriks dengan enzim alkalase menyebabkan menurunnya gugus fungsi eter yang merupakan gugus utama dari matriks silan. Dengan demikian, dapat disimpulkan bahwa enzim alkalase telah terimobilisasi.

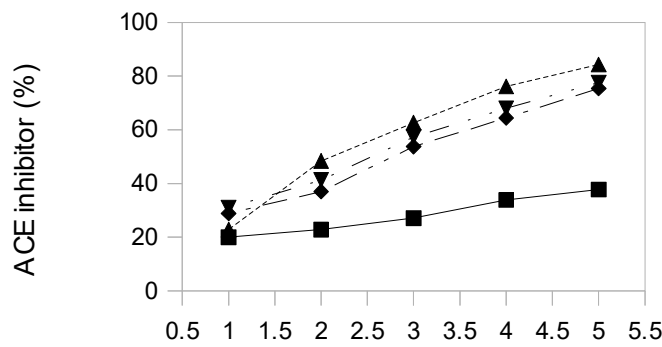

Konsentrasi uji $(\mu \mathrm{g} / \mu \mathrm{l})$

Gambar 5. Aktivitas ACE inhibitor protein isolat biji melinjo (Gg-PI), protein biji melinjo yang dihidrolisis dengan alkalase terimobilisasi (Gg-PH), protein biji melinjo yang dihidrolisis dengan alkalase bebas (Gg-PHB), dan kontrol positif (kaptopril)

Keterangan:

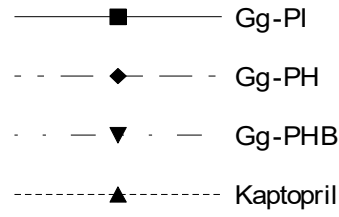

Ekstraksi dan isolasi protein biji melinjo Hasil produksi bertahap Gg-PK, Gg-PI, dan Gg-PH (Tabel 1) memiliki perbedaan dengan penelitian sebelumnya yang dilakukan oleh Sembodo pada perbandingan yang sama (1:3) [12]. Jumlah protein yang diperoleh adalah lebih besar. Perbedaan jumlah protein tersebut dapat disebabkan oleh perbedaan tempat tumbuh dari pohon melinjo. Pada penelitian sebelumnya, biji melinjo diperoleh dari petani daerah Jember yang merupakan daerah dataran sedang. Tanaman melinjo yang tumbuh di daerah dataran sedang memiliki kandungan protein yang lebih tinggi [13]. Hal tersebut menunjukkan bahwa ketinggian lokasi tumbuh mempengaruhi kandungan protein.

\section{Optimasi kondisi hidrolisis dan profil pita protein biji melinjo}

Hidrolisis dikatakan baik jika nilai derajat hidrolisis (DH) lebih dari $30 \%$ [14]. Enzim alkalase terimobilisasi yang efektif 
menghidrolisis hingga dua kali diharapkan dapat meminimalisir penggunaan enzim bebas yang kurang ekonomis. Pada Gambar 4, terlihat pita protein $\mathrm{Gg}-\mathrm{PK}$ dengan berat molekul $\pm 76, \pm 63$, \pm 26 , dan $\pm 14 \mathrm{KDa}$ terlihat jelas. Namun, pada protein $\mathrm{Gg}-\mathrm{PH}$ dengan berat molekul yang sama memperlihatkan pita protein yang mengalami pemudaran. Hal ini menunjukkan bahwa telah terjadi proses hidrolisis protein pada $\mathrm{Gg}-\mathrm{PH}$.

\section{Aktivitas antihipertensi protein biji melinjo} Aktivitas antihipertensi terendah terdapat pada Gg-PI. Hal tersebut dapat disebabkan karena $\mathrm{Gg}-\mathrm{PI}$ masih berada dalam bentuk makromolekul. Bentuk ini menyebabkan hanya sebagian saja Gg-PI yang dapat menempel pada catalytic site yang umumnya berbentuk celah. Seperti yang diketahui, catalytic site merupakan tempat pengikatan substrat atau proses katalis berlangsung. Semakin banyak protein yang menempel pada catalytic site, maka perubahan angiotensin I menjadi angiotensin II mampu dihambat [15]. Hal inilah yang menyebabkan $\mathrm{Gg}-\mathrm{PH}$ (bentuk mikromolekul) memiliki aktivitas antihipertensi yang lebih tinggi dibandingkan dengan Gg-PI.

Nilai $\mathrm{IC}_{50}$ menunjukkan kemampuan protein menghambat ACE sebanyak $50 \%$. Semakin kecil nilai $\mathrm{IC}_{50}$ maka semakin besar tingkat efisiensi penghambatannya terhadap ACE [16]. Gg-PI tidak ditentukan nilai IC50-nya dikarenakan aktivitas antihipertensi $\mathrm{Gg}-\mathrm{PI}$ tidak mencapai $50 \%$. Hasil analisis statistik menunjukkan antara $\mathrm{Gg}-\mathrm{PH}, \quad \mathrm{Gg}-\mathrm{PHB}$, dan kaptopril tidak ada perbedaan yang signifikan (LSD, $p>0,05)$, sehingga dapat dikatakan bahwa protein biji melinjo baik yang dihidrolisis dengan alkalase bebas dan terimobilisasi memiliki aktivitas yang sama seperti kaptopril.

\section{Simpulan dan Saran}

Kesimpulan yang dapat diambil dari penelitian yang telah dilakukan adalah enzim alkalase terimobilisasi efektif dalam menghidrolisis protein biji melinjo, ditandai dengan $\mathrm{DH}$ lebih dari $30 \%$ pada dua kali penggunaan dan protein hidrolisat biji melinjo (Gg-PH) memiliki aktivitas sebagai antihipertensi yang lebih tinggi dibandingkan protein isolat biji melinjo (Gg-PI), dengan nilai $\mathrm{IC}_{50} 2,457 \pm 0,213$ $\mu \mathrm{g} / \mu \mathrm{l}$. Untuk pemanfaatan protein hidrolisat biji melinjo sebagai antihipertensi secara maksimal perlu dilakukan uji lanjutan seperti uji in vivo, uji toksisitas, dan uji klinis.

\section{Ucapan Terima Kasih}

Terima kasih kepada Divisi Nutrasetikal dan Farmasetikal CDAST Universitas Jember yang telah mendanai penelitian ini.

\section{Daftar Pustaka}

[1] Depkes RI. Profil kesehatan Indonesia. Jakarta: Depkes RI; 2014.

[2] Dipiro JT, Talbert RL, Yee GC, Matzke GC, Wells BG, Posey LM. Pharmacotherapy seventh edition. New York: McGraw Hill; 2007.

$[3,6]$ Siswoyo TA, Sugiharto B. Produksi pengembangan protein antihipertensi generasi baru dari protein Gnetum gnemonsebagai bahan nutrasetikal komersial. Prosiding InSINas. 2012: 217222.

[4] Katchalski-Katzir E. Immobilized enzyme: learning from past successes and failures. Dept. Membr. Res. Biophys.1993: 11: 471-478.

[5] Reetz MT, Tielmann P, Wiesenhofer W, Konen W, Zonta A. Second generation solgel encapsulated lipases: robust heterogeneous biocatalysts. Adv. Synth. Catal. 2003: 345: 717-728.

[7] Adler-Nissen J. Determination of the degree of hydrolysis of food protein hydrolysates by titrobenzene sulfonic acid. Agric. Food Chem. 1979: 27 (6): 12561262.

[8] Bradford MM. A rapid and sensitive method for the quantitation of microgram quantities of protein utilizing the principle of protein-dye binding. Anal. Biochem. 1976: 72: 248-254.

[9] Laemmli UK. Cleavage of structural proteins during the assembly of the head of bacteriophage T4. Nature. 1970: 227: 680-685.

[10] Lam LH, Shimamura T, Manabe S, Ishiyama $M$, Ukeda $H$. Assay of angiotensin i- converting enzymeinhibiting activity based on the detection of 3-hydroxybutyrate with water soluble tetrazolium salt. Anal. Sci. 2008: 24: 1057-1060.

[11] Gokgoz M, Yigitoglu M. Immobilization of Saccharomyces cerevisiae on to modified carboxymethylcellulose for production of ethanol. Springer. 2011: $\quad 34: 849-857$.

[12] Sembodo TAP. Uji aktivitas secara in vitro dan kemampuan proteksi terhadap 
Matra, et al., Hidrolisis Protein Isolat Biji Melinjo (Gnetum gnemon L.) menggunakan Alkalase....

kerusakan DNA dari protein biji melinjo (Gnetum gnemon). Skripsi. 2015: Fakultas Kedokteran Universitas Jember.

[13] Wulaningrum N. Potensi protein antioksidan dari biji dan daun tanaman melinjo (Gnetum gnemon) pada ketinggian lokasi yang berbeda. Skripsi. 2013: Fakultas Pertanian Universitas Jember.

[14] Himonides AT, Taylor AKD, Morris AJ. A study of the enzymatic hydrolysis of fish frames using model systems. Food Nutr. Sci. 2011: 2: 575-585.
[15] Azhar KT, Siwoyo TA, Santosa A. Uji aktivitas protein isolat biji melinjo (Gnetum gnemon) sebagai antihipertensi secara in vivo. E-Jurnal Pustaka Kesehatan. 2014: 2(3): 382- 386.

[16] Febrisiantosa A, Purwanto BP, Arief IS, Widyastuti Y. Karakteristik fisik, kimia, mikrobiologi whey kefir dan aktivitasnya terhadap penghambatan angiotensin converting enzyme (ACE). J. Teknol dan Industri Pangan. 2013: 24(2): 147-153. 